\title{
Assessment of the Attitude of Prospective Teachers Enrolled in Postgraduate Diploma in Teaching: The Case of Wollega University
}

\author{
Adugna Bersissa Merdassa
}

College of Social Science, Wollega University Post Box No: 395, Nekemte, Ethiopia

\begin{tabular}{|c|c|}
\hline Abstract & Article Information \\
\hline \multirow{13}{*}{$\begin{array}{l}\text { The purpose of this study was to investigate prospective teachers' attitude } \\
\text { towards the teaching profession. Moreover, an attempt was made to explore } \\
\text { prospective teachers' attitude towards teaching in terms of some variables: } \\
\text { gender, family income, parents' level of education, reasons for choosing the } \\
\text { teaching profession, and perceived problems in the work place. The } \\
\text { participants of the study comprised of } 146 \text { prospective teachers from the four } \\
\text { departments/ programs (Amharic, English, Physics and Chemistry), which } \\
\text { were selected using cluster random sampling method. To measure the } \\
\text { attitude of prospective teachers' towards the profession of teaching, a } 40 \\
\text { items Likert type scale with } 5 \text { points was used. Descriptive statistics, } \\
\text { independent sample t-test and one way ANOVA were used in the analysis. } \\
\text { Statistically significant difference was observed among prospective teachers } \\
\text { in their attitude towards teaching profession in terms of reasons for choosing } \\
\text { teaching profession. Moreover, statistically significant difference was also } \\
\text { found among prospective teachers in their attitude towards teaching } \\
\text { profession in terms of perceived problems in the work place. In this study, } \\
\text { there was no evidence shown statistically significant differences among } \\
\text { prospective teachers' in their attitudes towards teaching profession in terms } \\
\text { of gender, family income, and parents' education level. }\end{array}$} & Article History: \\
\hline & Received : 23-10-2012 \\
\hline & : 15-12-2012 \\
\hline & Accepted : 18-12-2012 \\
\hline & Keywords: \\
\hline & Attitude \\
\hline & Family Income \\
\hline & Parents' Educational Level \\
\hline & Postgraduate Diploma in Teaching \\
\hline & ${ }^{*}$ Corresponding Author: \\
\hline & Adugna Bersissa Merdassa \\
\hline & E-mail: \\
\hline & adugnaber@yahoo.com \\
\hline
\end{tabular}

\section{INTRODUCTION}

Attitude towards teaching is formed by direct experience in the profession as well as transmitted from the general societal values attached to the teaching profession and the living conditions of the teachers. In other words, even though prospective teachers don't experience the challenges and opportunities of teaching profession directly, they feel almost in the same way as those teachers who are already in the job; because the attitude towards teaching is something to pass on them from the social values of the teachers in general and the living conditions of the teachers in particular (Halawah, 2008).

Capa and Cil (2000) suggested that to be successful in the teaching profession required patience, dedication and continuous operation, it is important to like it and willingly take up this profession. This means, the attitude developed toward the profession is one of the most important determinants of significant achievement of the individual in that profession. If teachers have positive attitudes toward teaching profession, it will positively influence their professional lives. On the contrary, if teachers have negative attitudes toward teaching profession, this will negatively influence their professional achievement (Kogce, Aydın and Yıldız, 2010). For this reason, it is crucial for the teachers to hold a positive attitude towards teaching if they wish to be successful in their profession. However, many research findings reveal that because of various reasons the majority of secondary school teachers are found to hold unfavorable attitudes towards teaching profession. Two major reasons are more important than others and are as follows. 
Adugna Bersissa Merdassa

Firstly, teachers' salaries, promotion, remuneration, and professional development are most important factors which could be called benefits (Ustuner, Demirtas, and Comert, 2009), and teachers in many countries are not satisfied with these benefits of their jobs. Secondly, it has also been found that how society values and respects teachers are important issues in teachers' attitudes toward teaching. Teachers viewed job dissatisfaction as principally contributed by perceptions of how teachers are viewed by the society (Michalinos and Elena, 2004). Similarly, Tadesse and Meaza (2007) found that attitude of student-teachers towards their profession is highly affected by the attitude of the society towards the profession. They maintained that the attitude of the society significantly affects trainees' attitude not to be interested in teaching profession, because the attitude of the society towards the profession is highly dependent on the income it generates to the individual and not on its contribution for societal change and development.

Attitudes of teachers have also been found to be influenced by gender (Guneyli and Aslan, 2009; Kogce, Aydın, and Yildiz, 2010; and Ustuner, Demirtas, and Comert, 2009). These scholars found that female teachers have more positive attitudes towards teaching profession than male teachers. They tried to explain the reason of that result as a stereotyping belief, that "teaching is a feminine job".

Currently in Ethiopia, the selection criteria and the training of prospective secondary school teachers is changed. Primarily, they join universities and graduate in applied programs/ departments. Then, those who are interested in the profession and can satisfy the requirement of MoE will be selected for the teaching profession. In the year 2011, among the students graduated in applied fields those with better CGPA preferred the teaching profession and enrolled themselves in the Postgraduate Diploma in Teaching (PGDT) to become secondary school teachers. But the fact that they preferred the teaching profession is not a guarantee for holding positive attitudes towards the profession because they can choose the profession for various reasons rather than for intrinsic reasons. Thus, the purpose of this study was to investigate prospective teachers' attitude towards the teaching profession. Moreover, an attempt was made to explore prospective teachers' attitude towards teaching in terms of different variables: gender, family income, parents' level of education, reasons for choosing the teaching profession, and perceived problems in the work place.
Sci. Technol. Arts Res. J., Oct-Dec 2012, 1(4):65-73

\section{MATERIALS AND METHODS}

\section{Study Site}

This study was conducted at one of the higher learning institutions in Ethiopia, Wollega University. Hence, the population of this study included all the prospective teachers enrolled in Postgraduate Diploma in Teaching (PGDT) in Wollega University in the summer of 2011.

\section{Sampling Technique}

There were 337 prospective teachers enrolled in PGDT in Wollega University in the summer 2011 in eight programs/ departments (Amharic, English, Math, Physics, Chemistry, Biology, Sport Science and Civics). Of the eight departments the researcher selected four departments (Amharic, English, Physics, and Chemistry) using cluster random sampling method. The total number of prospective teachers enrolled in these four departments/ programs were 146. All of the prospective teachers in the four departments/ programs participated in the study and completed the questionnaire for data collection. Among the questionnaires completed by the participants, 31 completed either wrongly or not fully were discarded and the remaining 115 were included in the analysis.

\section{Data Gathering Instrument}

Data was collected using a self-administered questionnaire. The questionnaire had two parts. The first part was dealing with participants' background and some other personal information. The second part was a 5-point Likerttype scale to measure participants "feelings" about teaching, which is a measure of their attitude towards teaching. The Attitude Scale was developed by the researcher and the final draft of the instrument contained 40 items. The Cronbach a-reliability coefficient of the scale was found to be 0.88 .

Here the attitude questionnaire consists of a set of equal number of favorable and unfavorable statements with which each subject is required to indicate the extent of his/ her agreement. Thus, 20 favorable statements and 20 unfavorable statements with degree of agreement ranging from strongly agree to strongly disagree were prepared. In the case of favorable statements strongly agree is scored 5, agree is scored 4, undecided is scored 3 , disagree is scored 2 , and strongly disagree is scored 1 . The values are reversed for unfavorable items. 
Adugna Bersissa Merdassa

\section{Statistical Analysis}

After the necessary data were collected and coded, quantitative analyses were performed using SPSS 17.01 (Statistical Package for the Social Sciences) for windows. Descriptive statistics, independent sample t-test and one way ANOVA were used in the analysis. Descriptive statistics was used to determine the attitude of prospective teachers towards teaching profession, independent sample t-test was used for binary comparison (gender), and one-way analysis of variance (ANOVA) and Tukey HSD test were used for multiple comparisons (family income, parents' education level, reasons for choosing teaching profession, and perceived problems in the work place).

\section{RESULTS}

\section{Percentage Distribution of the Participants in terms of Some Variables}

Participants of the study comprise of 93 male and 22 female prospective teachers. It was found that a greater number of prospective teachers (53
Sci. Technol. Arts Res. J., Oct-Dec 2012, 1(4):65-73

participants (46.1\%) and 46 participants $(40 \%))$ came from families whose income is equal to expenses and less than expenses respectively. Most of the prospective teachers (76 participants, $66.1 \%)$ enrolled in the post graduate diploma program graduated with CGPA greater than 3.00 from the universities. This implies that prospective teachers selected for the PGDT program had better academic performance.

When the reasons forwarded for choosing the teaching profession is considered, most of the participants (58 or $50.4 \%$ ) have chosen teaching based on their own personal interest, whereas the remaining 57 participants (49.6\%) prospective teachers have chosen the profession for different reasons. A greater number of the prospective teachers (67 participants, $58.3 \%$ ) indicated having financial problems will be their perceived problem in the teaching profession. These clearly indicate, among the couple of problems that makes worry the prospective teachers, the principal factor is economic problem as the salary and other benefits are less.

Table 1: The Numbers and percentages of prospective teachers in terms of some variables.

\begin{tabular}{llcc}
\hline & Variables & N & $\%$ \\
\hline \multirow{2}{*}{ Gender } & Male & 93 & 80.9 \\
& Female & 22 & 19.1 \\
\hline \multirow{4}{*}{ Department/Program } & Amharic & 25 & 21.7 \\
& English & 20 & 17.4 \\
& Physics & 37 & 32.2 \\
& Chemistry & 33 & 28.7 \\
\hline \multirow{2}{*}{ Family income } & Income less than expenses & 46 & 40.0 \\
& Income equal to expenses & 53 & 46.1 \\
& Income more than expenses & 16 & 13.9 \\
\hline \multirow{4}{*}{ CGPA at graduation } & Between 2.00-2.50 & 6 & 5.2 \\
& Between 2.50-3.00 & 33 & 28.7 \\
& Between 3.00-3.50 & 55 & 47.8 \\
& Between 3.50-4.00 & 21 & 18.3 \\
\hline \multirow{2}{*}{ Reasons for choosing } & Could not get the chance to be selected & 25 & 21.7 \\
teaching Profession & On the guidance of parents /friends & 10 & 8.7 \\
& Irelatives/teachers & 58 & 50.4 \\
& It is my own choice & 22 & 19.1 \\
\hline \multirow{2}{*}{$\begin{array}{l}\text { Perceived problem } \\
\text { the work place }\end{array}$} & To increase the chance for employment & 14 & 12.2 \\
& Professional inexperience / incapability & 67 & 58.3 \\
& Having financial problems & 12 & 10.4 \\
& Low social value & 22 & 19.1 \\
\hline
\end{tabular}

\section{Descriptive Statistics of the Attitude Scores}

As can be seen from Table 2, the mean score of the subjects on attitude scale is $141.99 \pm 21.17$ out of 200 or 3.55 out of 5 , which shows that the attitude of prospective secondary school teachers in general is moderately positive. The minimum attitude score is 76 (1.9 out of 5) and the maximum is 184 (4.6 out of 5). 
Table 2: Descriptive Statistics of the total attitude scores of the subjects.

\begin{tabular}{ccc}
\hline $\begin{array}{c}\text { SI. } \\
\text { No }\end{array}$ & Statistical Measure & Responses \\
\hline 1 & Mean & 141.99 \\
2 & Standard Deviation & 21.17 \\
3 & Minimum & 76.00 \\
4 & Maximum & 184.00 \\
\hline
\end{tabular}

\section{Attitude towards Teaching as a Function of Gender}

In order to find whether prospective teachers' attitudes towards the profession of teaching differ as a function of gender, independent t-test was performed, and the result is given in Table 3.
When Table 3 is examined, it can be seen that the attitudes of prospective teachers $(t)(113)=$ $0.12, \quad p=0.90>0.05$ ) showed no significant difference in terms of gender variable.

Table 3: Prospective teachers' attitudes towards the profession of teaching in terms of Gender.

\begin{tabular}{llllllll}
\hline & Gender & N & Mean & SD & df & $\mathbf{t}$ & $\mathbf{p}$ \\
\hline \multirow{2}{*}{ Attitude } & Male & 93 & 142.11 & 21.95 & 113 & 0.12 & 0.90 \\
\cline { 2 - 7 } & Female & 22 & 141.50 & 17.95 & & & \\
\hline
\end{tabular}

\section{Attitude towards Teaching as a Function Family Income}

The result of one-way ANOVA performed in order to determine whether there is a statistically significant difference among prospective teachers in their attitudes toward teaching profession in terms of family income is presented in Table 4.

In terms of family income variable, the attitudes of prospective teachers $(F(2,112)=$
$0.52, p=0.59>0.05)$ toward teaching profession showed no significant difference. But when mean attitude scores are considered (income less than expenses $=144.28$, income equal to expenses $=141.02$, and income more than expenses=138.62), prospective teachers having family incomes less than expenditures showed more positive attitudes toward teaching than those whose family income is equal to and more than expenditures.

Table 4: The attitudes of prospective teachers toward teaching profession in terms of family income.

\begin{tabular}{cccccc}
\hline Sources & $\begin{array}{c}\text { Sum of } \\
\text { Squares }\end{array}$ & df & $\begin{array}{c}\text { Mean } \\
\text { Square }\end{array}$ & F & Significance \\
\hline Between Groups & 472.934 & 2 & 236.467 & 0.52 & 0.59 \\
Within Group & 50630.057 & 112 & 452.054 & & \\
Total & 51102.9912 & 114 & & & \\
\hline
\end{tabular}

\section{Attitude towards Teaching as a Function of} Educational level of Parents

The results of one-way ANOVA performed in order to determine whether there is a statistically significant difference among prospective teachers in their attitudes toward teaching in terms of parents' level of education are presented in Table 5. 
Table 5: Attitudes of prospective teachers towards teaching profession in terms of educational level of parents.

\begin{tabular}{ccccccc}
\hline & Sources & $\begin{array}{c}\text { Sum of } \\
\text { Squares }\end{array}$ & df & $\begin{array}{c}\text { Mean } \\
\text { Square }\end{array}$ & F & Significance \\
\hline $\begin{array}{c}\text { Fathers' } \\
\text { Educational } \\
\text { Level }\end{array}$ & Between Groups & 11.522 & 2 & 5.761 & 0.013 & 0.987 \\
& Within Group & 51091.469 & 112 & 456.174 & & \\
\hline $\begin{array}{l}\text { Mothers' } \\
\begin{array}{l}\text { Educatio } \\
\text { nal Level }\end{array}\end{array}$ & Between Groups & 124.772 & 2 & 62.368 & 0.137 & 0.872 \\
& Within Group & 50978.220 & 112 & 455.163 & & \\
\hline
\end{tabular}

According to father's education level variable, the attitudes of prospective teachers $(F(2,112)$ $=0.013, \quad \mathrm{p}=0.987>0.05)$ toward teaching profession showed no significant difference. But, when we look at the mean scores (primary school or lower $=141.82$, high school $=142.57$, and higher education=142.58), prospective teachers whose paternal level of education are higher than others showed slightly more positive attitudes. Similarly, according to mother's education level variable, the attitudes of prospective teachers $(F(2,112)=0.137, p=0.872$ $>0.05$ ) toward teaching profession showed no significant difference. But, when we look at the mean scores (primary school or lower $=143.50$, high school=142.09 \& higher education=137.40), prospective teachers whose maternal level of education are lower than others showed more positive attitudes towards teaching profession.

\section{Attitude towards Teaching as a Function of Reasons for Choosing}

The result of one-way ANOVA performed in order to determine whether there is a statistically significant difference among prospective teachers in their attitudes toward teaching profession in terms of reasons for choosing teaching profession is presented in Table 6.

Table 6 shows that statistically significant difference is observed $(F(3,111)=5.075, P=$ $0.002<0.05)$ among prospective teachers in their attitudes towards teaching profession, according to reasons for choosing the profession. The following Tukey HSD test table illustrates which group is different from which.

Table 6: Prospective teachers' attitudes towards the profession of teaching in terms of reasons for choosing the profession.

\begin{tabular}{cccccc}
\hline Sources & $\begin{array}{c}\text { Sum of } \\
\text { Squares }\end{array}$ & df & $\begin{array}{c}\text { Mean } \\
\text { Square }\end{array}$ & F & Significance \\
\hline Between Groups & 6163.878 & 3 & 2054.626 & 5.075 & 0.002 \\
Within Group & 44939.114 & 111 & 404.857 & & \\
Total & 51102.991 & 114 & & & \\
\hline
\end{tabular}

As can be seen from table 7 , the difference that is statistically significant was observed between those prospective teachers who have chosen the teaching profession by being influenced by parents/friends/relatives/teachers and those who have chosen the profession based on their personal interest i.e. prospective teachers who preferred the teaching profession based on their personal interest have shown more positive attitudes towards teaching as compared with those who preferred the profession on the influence of others. Another statistically significant difference observed was between those who preferred the teaching profession based on their personal interest and those who preferred the profession to get employment opportunity i.e. prospective teachers who preferred the teaching profession to increase their chance for employment have shown more unfavorable attitudes towards the teaching profession than those who preferred the profession based on their personal interests. 
Table 7: Tukey HSD test of attitude scores of prospective teachers in terms of reasons for choosing teaching.

\begin{tabular}{|c|c|c|c|c|c|c|}
\hline \multirow{2}{*}{$\begin{array}{l}\text { Reasons for } \\
\text { Choosing } \\
\text { Teaching }\end{array}$} & \multirow{2}{*}{$\begin{array}{c}\text { Reasons for Choosing } \\
\text { Teaching }\end{array}$} & \multirow{2}{*}{$\begin{array}{c}\text { Mean } \\
\text { Difference } \\
(\mathrm{I}-\mathrm{J})\end{array}$} & \multirow{2}{*}{$\begin{array}{l}\text { Std. } \\
\text { Error }\end{array}$} & \multirow[t]{2}{*}{ Sig. } & \multicolumn{2}{|c|}{$\begin{array}{c}95 \% \text { Confidence } \\
\text { Interval }\end{array}$} \\
\hline & & & & & $\begin{array}{l}\text { Lower } \\
\text { Bound }\end{array}$ & $\begin{array}{l}\text { Upper } \\
\text { Bound }\end{array}$ \\
\hline \multirow{3}{*}{$\begin{array}{l}\text { Could not get } \\
\text { the chance to } \\
\text { be selected for } \\
\text { University } \\
\text { instructor }\end{array}$} & $\begin{array}{l}\text { On the guidance of parents } \\
\text { /friends/relatives/teachers }\end{array}$ & 16.2200 & 7.52861 & 0.143 & -3.4175 & 35.8575 \\
\hline & It is my own choice & -6.8972 & 4.81400 & 0.482 & -19.4540 & 5.6595 \\
\hline & $\begin{array}{c}\text { To increase the chance for } \\
\text { employment }\end{array}$ & 6.2564 & 5.88191 & 0.712 & -9.0859 & 21.5986 \\
\hline \multirow{3}{*}{$\begin{array}{l}\text { On the } \\
\text { guidance of } \\
\text { parents/ } \\
\text { friends/ } \\
\text { relatives/ } \\
\text { teachers }\end{array}$} & $\begin{array}{l}\text { Could not get the chance to } \\
\text { be selected for University } \\
\text { instructor }\end{array}$ & -16.2200 & 7.52861 & 0.143 & -35.8575 & 3.4175 \\
\hline & It is my own choice & $-23.1172\left(^{*}\right)$ & 6.88956 & 0.006 & -41.0878 & -5.1467 \\
\hline & $\begin{array}{c}\text { To increase the chance for } \\
\text { employment }\end{array}$ & -9.9636 & 7.67387 & 0.566 & -29.9800 & 10.0527 \\
\hline \multirow{3}{*}{$\begin{array}{l}\text { It is my own } \\
\text { choice }\end{array}$} & $\begin{array}{l}\text { Could not get the chance to } \\
\text { be selected for University } \\
\text { instructor }\end{array}$ & 6.8972 & 4.81400 & 0.482 & -5.6595 & 19.4540 \\
\hline & $\begin{array}{l}\text { On the guidance of parents } \\
\text { /friends/relatives/teachers }\end{array}$ & $23.1172\left(^{*}\right)$ & 6.88956 & 0.006 & 5.1467 & 41.0878 \\
\hline & $\begin{array}{c}\text { To increase the chance for } \\
\text { employment }\end{array}$ & $13.1536\left(^{*}\right)$ & 5.03814 & 0.050 & 0.0122 & 26.2950 \\
\hline \multirow{3}{*}{$\begin{array}{l}\text { To increase the } \\
\text { chance for } \\
\text { employment }\end{array}$} & $\begin{array}{l}\text { Could not get the chance to } \\
\text { be selected for University } \\
\text { instructor }\end{array}$ & -6.2564 & 5.88191 & 0.712 & -21.5986 & 9.0859 \\
\hline & $\begin{array}{l}\text { On the guidance of parents } \\
\text { /friends/relatives/teachers }\end{array}$ & 9.9636 & 7.67387 & 0.566 & -10.0527 & 29.9800 \\
\hline & It is my own choice & $-13.1536\left(^{*}\right)$ & 5.03814 & 0.050 & -26.2950 & -0.0122 \\
\hline
\end{tabular}

* The mean difference is significant at the 0.05 level.

\section{Attitude towards Teaching as a Function of Perceived Problems}

The result of one-way ANOVA performed in order to determine whether there is a statistically significant difference among prospective teachers in their attitudes toward teaching profession in terms of perceived problem in the work place is presented in Table 8.
As indicated in Table 8 , there is statistically significant difference $(\mathrm{F}(3,111)=3.474, \mathrm{P}=0.019$ $<0.05$ ) among prospective teachers in their attitudes towards teaching profession, according to perceived problems in the work place. The following Tukey HSD test Table, shows which group is different from which.

Table 8: Prospective teachers' attitudes towards the profession of teaching in terms of perceived problems.

\begin{tabular}{cccccc}
\hline Sources & Sum of Squares & df & $\begin{array}{c}\text { Mean } \\
\text { Square }\end{array}$ & F & Significance \\
\hline Between Groups & 4386.044 & 3 & 1462.015 & 3.474 & 0.019 \\
Within Group & 46716.947 & 111 & 420.873 & & \\
Total & 51102.991 & 114 & & & \\
\hline
\end{tabular}

As illustrated in Table 9, the only difference that is statistically significant is between those prospective teachers who perceived that they will face financial problems and those who perceived that it will be difficult to deal with students misbehaviors i.e. prospective teachers who perceived that they will face financial problems as a teacher, have shown more unfavorable attitudes toward the profession of teaching than those who perceived they will be challenged to manage students misbehaviors. 
Table 9: Tukey HSD test of attitude scores of prospective teachers in terms of the perceived problems.

\begin{tabular}{|c|c|c|c|c|c|c|}
\hline \multirow{2}{*}{$\begin{array}{c}\text { Perceived } \\
\text { problem } \\
\text { after } \\
\text { graduation }\end{array}$} & \multirow{2}{*}{$\begin{array}{l}\text { Perceived problem } \\
\text { after graduation }\end{array}$} & \multirow{2}{*}{$\begin{array}{c}\text { Mean } \\
\text { Difference } \\
(\mathrm{I}-\mathrm{J})\end{array}$} & \multirow[t]{2}{*}{ Std. Error } & \multirow[t]{2}{*}{ Sig. } & \multicolumn{2}{|c|}{$\begin{array}{c}\text { 95\%Confidence } \\
\text { Interval }\end{array}$} \\
\hline & & & & & $\begin{array}{l}\text { Lower } \\
\text { Bound }\end{array}$ & $\begin{array}{l}\text { Upper } \\
\text { Bound }\end{array}$ \\
\hline \multirow{3}{*}{$\begin{array}{c}\text { Professional } \\
\text { inexperience/ } \\
\text { incapability }\end{array}$} & $\begin{array}{l}\text { Having financial } \\
\text { problems }\end{array}$ & 11.8593 & 6.02861 & 0.207 & -3.8656 & 27.5842 \\
\hline & Low social value & 7.4762 & 8.07064 & 0.791 & -13.5751 & 28.5275 \\
\hline & $\begin{array}{c}\text { Dealing with students } \\
\text { misbehaviors }\end{array}$ & -2.8117 & 7.01377 & 0.978 & -21.1063 & 15.4829 \\
\hline \multirow{3}{*}{$\begin{array}{l}\text { Having } \\
\text { financial } \\
\text { problems }\end{array}$} & $\begin{array}{c}\text { Professional } \\
\text { inexperience/ } \\
\text { incapability }\end{array}$ & -11.8593 & 6.02861 & 0.207 & -27.5842 & 3.8656 \\
\hline & Low social value & -4.3831 & 6.43074 & 0.904 & -21.1569 & 12.3907 \\
\hline & $\begin{array}{c}\text { Dealing with students } \\
\text { misbehaviors }\end{array}$ & $-14.6710\left(^{*}\right)$ & 5.04106 & 0.022 & -27.8200 & -1.5220 \\
\hline \multirow{3}{*}{$\begin{array}{l}\text { Low social } \\
\text { value }\end{array}$} & $\begin{array}{c}\text { Professional } \\
\text { inexperience/ } \\
\text { incapability }\end{array}$ & -7.4762 & 8.07064 & 0.791 & -28.5275 & 13.5751 \\
\hline & $\begin{array}{l}\text { Having financial } \\
\text { problems }\end{array}$ & 4.3831 & 6.43074 & 0.904 & -12.3907 & 21.1569 \\
\hline & $\begin{array}{c}\text { Dealing with students } \\
\text { misbehaviors }\end{array}$ & -10.2879 & 7.36230 & 0.504 & -29.4915 & 8.9158 \\
\hline \multirow{3}{*}{$\begin{array}{l}\text { Dealing with } \\
\text { students } \\
\text { misbehaviors }\end{array}$} & $\begin{array}{c}\text { Professional } \\
\text { inexperience / } \\
\text { incapability }\end{array}$ & 2.8117 & 7.01377 & 0.978 & -15.4829 & 21.1063 \\
\hline & $\begin{array}{l}\text { Having financial } \\
\text { problems }\end{array}$ & $14.6710\left(^{*}\right)$ & 5.04106 & 0.022 & 1.5220 & 27.8200 \\
\hline & Low social value & 10.2879 & 7.36230 & 0.504 & -8.9158 & 29.4915 \\
\hline
\end{tabular}

* The mean difference is significant at the $p<05$ level.

\section{DISCUSSION}

Prospective teachers, who were studying in different departments/ programs generally possessed moderately positive attitude towards the teaching profession. The mean score of the subjects on attitude scale is 141.99 (3.55 in the five point Likert scale). This finding is consistent with the work of Guneyli and Aslan (2009); Akbulut and Karaku (2011), who observed that a majority of prospective teachers have adopted a positive attitude towards their profession. However, the result of this study is inconsistent with the findings of Onyishi (1999); Hussain et al. (2011); and Osunde and Izevbigie (2006), who investigated that the majority of the secondary school teachers do not possess positive attitude towards the profession. According to these scholars, poor benefits will lead to dissatisfaction and hence give rise to unfavorable attitudes towards teaching profession. Moreover, according to Michalinos and Elena (2004); Halawah (2008); and Tadesse and Meaza (2007), low social values toward teaching profession significantly contribute to the negative attitudes among prospective teachers towards the profession. In this study, even though prospective teachers mean score on attitude scale implies positive attitude towards teaching profession, the fact that their future worry became financial problems might be an indication that they like the profession not for the salaries and other financial benefits are attractive, but for some other advantages like for further education and to secure job opportunity.

As a result of the study, statistically significant difference was not found among prospective teachers' in their attitude towards the profession of teaching in terms of gender. This finding is not congruent with the results of various studies conducted on pre-service teachers by Kogce, Aydın, and Yıldız (2010); Ustuner, Demirtas and Comert (2009) that female prospective teachers' attitude towards the profession of teaching is more positive than male prospective teachers' attitude. In their study, Kogce, Aydın, and Yıldız (2010) attributed the reason why female prospective teachers possess more positive attitude towards teaching profession than male prospective teachers, to the predisposition of 


\section{Adugna Bersissa Merdassa}

females to teaching profession due to some social and psychological reasons. They explained that in the social structure of Turkish society, it's thought that the attitudes of females are higher than males because girls are encouraged to teaching profession more frequently than boys. The fact that statistically significant difference was not observed between male and female prospective teachers in their attitudes towards teaching profession in this study might be due to the nonexistence of discriminative encouragement for girls to be teachers than boys in Ethiopia.

Also, the attitudes of prospective teachers toward teaching profession showed no significant difference in terms of family income. But when the mean attitude scores are considered prospective teachers having family incomes less than expenditures showed more positive attitudes toward teaching than those from family income equal to or more than expenditures. This result is similar with the findings of Okcabol and Gok (1998), and Simsek (2005) as cited in Guneyli and Aslan (2009), who pointed out that due to the low level of income, teaching is usually preferred by individuals from low income groups as compared to individuals from middle and high income families. In other words, students from low income families prioritize getting employed regardless of the amount of salary they earn. Thus, they do not underestimate the salary earned from the teaching profession as those students from middle and high income families.

The result of this study further revealed that the attitude of prospective teachers toward teaching profession showed no significant difference in terms of father's and mother's education level. But when the mean scores are analyzed, prospective teachers whose paternal level of education were higher than others showed slightly more positive attitudes, while prospective teachers whose maternal level of education were lower than others showed slightly more positive attitudes towards teaching profession. This finding is in line with the result of the work of Celikoz and Cetin (2004) as cited in Kogce, Aydın, and Yıldız (2010), who investigated a positive relationship between father's level of education and students' attitudes toward teaching profession and showed that as maternal level of education decreased, the attitudes toward teaching profession increased.

On the other hand, statistically significant difference was observed among prospective teachers in their attitudes towards the profession of teaching, according to reasons for choosing
Sci. Technol. Arts Res. J., Oct-Dec 2012, 1(4):65-73

the profession. Specifically, significant difference was observed between those prospective teachers who selected teaching profession on the influence of parents/friends/relatives/teachers and those who selected the profession based on their personal interest i.e. prospective teachers who selected the teaching profession based on their personal interest have shown more positive attitudes towards teaching as compared with those who selected the profession on the influence of others. Another statistically significant difference observed was between those who selected the teaching profession based on their personal interest and those who preferred the profession to get employment opportunity i.e. prospective teachers who selected the teaching profession to increase their chance for employment have shown more unfavorable attitudes towards the teaching profession than those who selected the profession based on their personal interests.

The result of the study has also shown that most of the participants (58 prospective teachers or $50.4 \%$ ) selected teaching profession based on their own personal interest. This finding is in line with the study conducted by Guneyli and Aslan (2009), which discovered that most of the prospective teachers selected teaching profession for they were enjoying the profession, aptness/suitability for the profession. In this study, an insignificant number of participants (57 prospective teachers or $49.6 \%$ ) selected teaching profession for various reasons (for they didn't get the chance to be university instructor, to increase their employment opportunity, and on the influence of parents/friends/ relatives/ teachers). In other words, almost half of the prospective teachers selected teaching profession and enrolled in Postgraduate Diploma in Teaching (PGDT) for various reasons without having intrinsic motivations. So, the question is to what extent such prospective teachers who were enrolled in PGDT for various reasons rather than intrinsic motivations will become fruitful.

Similarly, statistically significant difference was investigated among prospective teachers' in their attitudes towards teaching profession in terms of perceived problems in the work place. The only difference that is statistically significant was discovered between those prospective teachers who perceived that they will face financial problems and those who perceived that it will be difficult to deal with students misbehaviors i.e. prospective teachers who perceived that they will face financial problems as a teacher, have shown more negative attitudes towards the profession of teaching than those who perceived they will be 


\section{Adugna Bersissa Merdassa}

challenged to manage students misbehaviors. The result of the study further revealed that most of the participants $(58.26 \%)$ perceived financial problems to be the most serious challenge they will face in the work place. This finding is inconsistent with the finding of Guneyli and Aslan (2009), who discovered that the first of the two biggest perceived problems of prospective teachers is "Not being appointed" (33.3\%), and the second is "The obligation to get a high score in the public personnel selection examination" $(23.9 \%)$. The fact that the participants of this study, didn't worry about not being appointed is because they were given a promise by the government to be employed.

\section{CONCLUSION}

It was found that prospective teachers possess positive attitudes towards teaching profession. Statistically significant difference was not found among prospective teachers in their attitudes towards teaching profession in terms of gender, family income, and parents' level of education. Statistically significant difference was observed among prospective teachers in their attitudes towards teaching as profession in terms of reasons for choosing teaching profession. Prospective teachers who selected teaching profession based on their personal interest have shown more positive attitudes towards teaching profession than those who selected the profession on the influence of others and those who selected the profession to get employment opportunity. Statistically significant difference was also found among prospective teachers' in their attitudes towards teaching profession according to perceived problems in the work place. Prospective teachers, who perceived that they will face financial constraint as a teacher, have shown more negative attitudes towards the profession than those who perceived.

\section{REFERENCES}

Akbulut, O. E. and Karaku, F. (2011). The investigation of secondary school science and mathematics preservice teachers' attitudes towards teaching profession. Educational Research and Reviews 6(6):489-496.

Capa, Y. and Cil, N. (2000). Teachers' attitudes towards teaching profession: an investigation of the different variables. Hacettepe University Journal of Education 18: 69-73.

Guneyli, A. and Aslan, C. (2009). Evaluation of Turkish prospective teachers' attitudes towards teaching profession (Near East University case). Procedia Social and Behavioral Sciences 1: 313-319.
Sci. Technol. Arts Res. J., Oct-Dec 2012, 1(4):65-73

Halawah, I. (2008). Factors influencing perspective teachers' attitudes toward teaching. University of Sharjah Journal for Humanities \& Social Sciences 5(1): 151-162.

Hussain, S., Ali, R., Khan, M. S., Ramzan, M., Qadeer, and M. Z. (2011). Attitude of secondary school teachers towards teaching profession. International Journal of Academic Research 3(1):985-990.

Kogce, D., Aydın, M., Yildiz , C. (2010). Freshman and senior pre-service mathematics teachers' attitudes toward teaching profession. The International Journal of Research in Teacher Education 2(1):2-18.

Michalinos, Z. and Elena, P. (2004). Job satisfaction among school teachers in Cyprus. Journal of Educational Administration 42(3): 357-374.

Onyishi, B.O. (1999). Secondary school teachers' conditions of service and professional duties: implication for qualitative education in Nigeria. A Book of Readings. Enugu: University Trust Publishers.

Osunde, A.U and Izevbigie, T.I. (2006). An assessment of teachers' attitude towards teaching profession in Midwestern Nigeria. Education 126(3): 462-467.

Tadesse, W. and Meaza, F. (2007). Assessment on problems of the new pre-service teachers training program In Jimma University. Ethiopian Journal of Education and Sciences 2(2): 63-72.

Ustuner, M., Demirtaş, H. and Comert, M. (2009). The attitudes of prospective teachers towards the profession of teaching (The Case of Inonu University, Faculty of Education). Education and Science 34(151):140-155. 